\title{
Volter Kilpeä englanniksi
}

Douglas Robinson 
len Hongkongissa asuva amerikkalainen suomalaisen kirjallisuuden englannintaja: tiedän, kuulostaa oudolta! Suomessahan pitäisi asua, tai vähintään kohdekulttuurissani, englanninkielisessä maailmassa. Mutta elämä viskaa yllättävällä tavalla. Emme kaikki voi asua koko ikäämme kotipitäjässä kuten Volter Kilpi.

Tänä vuonna julkaistaan kaksikin uutta suomalaisen kirjallisuuden englanninnostani. Toinen on Mia Kankimäen Naiset joita ajattelen öisin -muistelmateoksen käännös, jonka Simon \& Schuster julkaisee nimellä The Women I Think About at Night (Robinson, käänt. 2020a). Mian kanssa keskusteltiin pitkästi, seikkaperäisesti ja aina innolla sekä mielenkiinnolla käännösratkaisuista. Nykykirjallisuuden englannintaminen on siitä hauskaa, että kirjailijat aina osaavat hyvin englantia ja osallistuvat älyllä ja tunteella prosessiin.

Toinen tänä vuonna julkaistava englanninnokseni on Gulliver's Voyage to Phantominia (Robinson, käänt. 2020b). Sen tekijän, Volter Kilven (1874-1939), kanssa ei valitettavasti pystytty keskustelemaan käännösratkaisuista: hänhän kuoli kesken kirjoittamisprosessin. Aikamatkustusromaani Gulliverin matka Fantomimian mantereelle jäi pahasti kesken. Vilho Suomi (toim. 2015) julkaisi sen tynkänä viisi vuotta kirjailijan kuoleman jälkeen.

Suuren suomalaisen modernistin jälkeen- ja keskenjääneen teoksen julkaiseminen sellaisenaan suomeksi suomalaisille on täysin ymmärrettävää - sehän on Kilpeä! Mutta mikä ihme saa englanninkielisen kääntäjän kiinnostumaan melko perifeerisen keskenjääneen suomenkielisen teoksen kääntämisestä? Kilpeähän ei ole ennen kertaakaan - lyhyitä pätkiä ${ }^{2}$ lukuunottamatta - julkaistu englanniksi. Eikö jälkeenjäänyt Gulliverin tynkä ole ensimmäiseksi englanninnettavaksi Kilveksi aika yllättävä valinta? Kiinnostukseni valaisemiseksi luon alla yleiskatsauksen Kilven koko myöhäistuotantoon ja sen englannintamisen ongelmakenttään.

\section{Onko Alastalon salissa mahdoton kääntää?}

Tutkiessamme Volter Kilven englanninnoshistoriaa, törmäämme heti David Barrettin (1996) julistukseen, että Kilpeä on mahdoton kääntää:

Vastahakoisesti (olen tosissani yrittänyt!) olen joutunut toteamaan, että Alastaloa ei pysty kääntämään muu kuin fanaattinen Volter Kilven harrastaja, joka olisi valmis koko elinikänsä sille omistamaan. Mainitakseni vain yhden vaikeuksista: ei ole englanninkielistä vastinetta sille suomalaiselle sananlaskutyylille (todelliselle tai kuvitellulle), jota Alastalon ajatukset ovat pullollaan. Kun siihen lisää Kilven sanaston rikkauden ja (kyllä vain) omituisuuden sekä sen, että suurin osa merenkulkuyhteisön ja sen intressien aihepiiristä on englanniksi tuntematonta, ja vielä sen, ettei siitä yhteisöstä 
ole enää rippeitäkään jäljellä, edes Turun saaristossa, kädessäsi on sudenkuoppia täynnänsä oleva käännettävä teksti. Huumorin osalta on valitettavasti todettava, että se on niin kiinni Kilven sanaparsissa ja esityksessä, ettei se siirry laisinkaan kohdetekstiin. Jos kääntäisin eteenpäin, joutuisin turvautumaan työlääseen parafraasiin, enkä usko pystyväni tekemään siitä tehokasta tai edes luettavaa englanninkielistä vastinetta. (suom. DR) ${ }^{1}$

Tätä otetta lukiessani tulin kysyneeksi, olisinko itse juuri sellainen "fanaattinen Volter Kilven harrastaja”, joka pystyisi kääntämään Alastalon englanniksi? En kuitenkaan vielä: olen kokenut suomesta englannintaja, joka on kääntänyt paitsi Aleksis Kiveä (Robinson 1993; 2017b; ks. myös Robinson 2017a) myös Kilpeä, mutta Alastalo on niin vaativa käännettävä, että se saa odottaa eläkevuosiani. Vaikka englanninkielinen Kilpi on siis vielä aika lailla alullaan, on siitä projektista jo silti sen verran näyttöä, että voidaan punnita sitä, olisiko David Barrett ollut väärässä.

Barrettin uumoilut koskivat nimenomaan Kilven suurteosta. Kirjaa lukiessa on heti selvää, että Kilpi on jättänyt varhaistuotantonsa uusromantiikan ja omaksunut varhaisromantiikan sokraattisen ironian:

Sokraattinen ironia on ainoa täysin ei-mielivaltainen, jopa täysin loppuun ajateltu valepuku. Sitä on yhtä mahdoton taiteilla tai paljastaa. [--] Siinä kaiken pitää olla samalla vitsi ja vakavissaan, samalla vilpittömän avointa ja syvällisellä tavalla naamioitua. [--] Se pitää sisällään ja herättää sen tunteen, että ehdollistettu ja ehdollistamaton ovat ratkaisemattomasti ristiriidassa keskenään - tunteen täydellisen viestinnän sekä mahdottomuudesta että välttämättömyydestä. Se on kaikista vapauksista vapain, sillä sen kautta ihminen asettuu itsensä yli; ja myös kaikkein lainmukaisin, sillä se on ehdottomasti tarpeen. On erittäin hyvä merkki, etteivät sopusointuiset poroporvarit alkuunkaan osaa suhtautua tähän jatkuvaan itseparodiaan, joka pakottaa heitä kerta toisensa jälkeen ensin uskomaan ja sitten olemaan uskomatta, kunnes heitä alkaa huimata, ja he alkavat pitää vitsejä vakavina ja vakavuutta vitsinä. (Schlegel 1956, 86-87; suom. DR; kursivointi lisätty)²

On houkuttelevaa spekuloida, että 1930-luvun suomalaiset "sopusointuiset poroporvarit" tyrmäsivät Kilven modernistisia tyylikokeiluja juuri sen vuoksi, etteivät osanneet "suhtautua tähän jatkuvaan itseparodiaan, joka pakottaa heitä kerta toisensa jälkeen ensin uskomaan ja sitten olemaan uskomatta" - että esimerkiksi Pitäjän pienempien (1934) arvostelussaan Yrjö Kivimiestä alkoi "huimata", ja että tämä esteettinen huimaus pani hänet purnaamaan, että "sellaista suomalais-ugrilaista mielipuolta ei vielä toistaiseksi ole maailmaan syntynyt, joka suustaan päästäisi tuollaista mesopotamian kieltä!” (sit. Rojola 1995, 76). Sillä kieltämättä Kilpi vaati - ja edelleenkin vaatii - lukijaltaan paljon: 
Pukkila sieppasi reiviä juttuun. "Kaiketikkin, kaiketikkin!" pani hän ja pakisi partaansa. Ei suinkaan teertä ennen ammuta kuin hollilta ja porstuassakos hän räiskyttäisi tyhjille seinille sen, mikä vasta salissa kärventäisi Alastalon leukakarvoja, kun makean on todistamassa tusina persoa korvaparia yht'ympärillä! Vielä rantamäkeä ylösastuessaan oli hän sanonut Evaldille, pojalleen: "rakentakoot, parkin-parkin, minun puolestani parkin-parkin, mutta kyllä minä suolaan-suolaan, suolaan-suolaan! Alastalolla ovat isoset korvalehdet, kuninkaalliset korvalehdet, haavit korvalehdiksi, päästetään vähän sanahyttystä hurisemaan niihin: niihin mahtuu! [--] En minä ole pieni, enkä minä ole isonen, minä olen Pukkila, minä, ja Pukkilan kielenpalanen on minun suussani! Älä sinä naura, Evald, en minäkään naura, kun minulta pääsee piru parrasta, mutta katsele, kun muut nauravat, Evald, sillä lailla minäkin katselen!" oli hän vielä neuvonut poikaansa, kun he jo pyyhkivät jalkojaan kuistinedustan tuuheaan havutukkuun. - "Kaiketikkin-kaiketikkin!" jupisi siis Pukkila vain omia sanojaan Alastalon härnäämisiin. "Kanitti-kanitti tuulikin-tuulikin vastaan-vastaan Kivivedellä-Kivivedellä!" puheli hän puheenväliä katkaistakseen ja kieltänsä lipeällä pitääkseen, jott'ei toinen pääsisi enempää karvasta tiputtamaan korvaan: silmät vahtasivat jo Alastalon olan ylitse tampuurin lävitse saliin. (Kilpi 2015, 23-24; kursivointi lisätty)

Jos luemme katkelman siinä toivossa, että löytäisimme siitä Kilven - jos oletamme että edes joku romaanin henkilöistä puhuisi meille suoraan kirjailijan suulla -, meitäkin varmasti huimaisi. Onko Pukkila Kilven suukappale vai räkättävä rakkikoira? Samaistuuko Kilpi Pukkilaan, vai satirisoiko? Joko-tai, päätä nyt perkele! Jos tunnemme lukiessa tarvetta stabiloida tällaiset kahtiajaot, kimpaannumme ennen pitkää Kilpeen: juonikas kirjailija. Sopusoituisina poroporvareina emme osaa asennoitua, ja lyömme turhautuneina kirjan kannet kiinni.

Jos taas luemme kohdan - ja koko romaanin - sokraattisena ironiana, käy pian ilmi, että varsinkin Pukkila (mutta muutkin laivanrakentajat samaten) on Kilven valepuku, ja että tuo valepuku ei ole millään lailla mielivaltainen, vaan "täysin loppuun ajateltu". Kilpi ei ole "taiteillut" (saksaksi erkünstelt) eli tekaissut sitä - se ei ole mikään peiteidentiteetti tai peitetarina - eikä sitä sen vuoksi voisi "paljastaa" joko Kilven omaksi ääneksi tai satiiriksi. Se on "syvällisellä tavalla naamioitua", mutta myös "samalla vilpittömän avointa".

Yksinkertaisemmin ilmaistuna, Kilven teksti toimii monella tasolla, ja tasot ovat usein strategisesti ristiriidassa keskenään. Kuten Alastalon tutkijat ovat todenneet, on usein vaikea paikantaa, kuka puhuu, ja onko kyse puheesta vai ajattelusta, vai olisiko teksti mahdollisesti jotain siltä väliltä. Onko Pukkila ylläolevassa jaksossa kertoja, vai onko kaikkitietävä kertoja jotenkin Pukkilan aivojen sisällä, vai siirtyykö kertojuus lauseittain paikasta ja persoonasta toiseen? Puhuuko Pukkila Evaldille ääneen, vai ajatteleeko hän nuo sanat, vai ovatko ne outo puhutun ja ajatellun törmäys? 
Tämä on sokraattista ironiaa kerrontateknisellä tasolla. Syvemmällä Kilven tekstin sokraattinen ironia kaivaa maata yksilön ja yksilöllisyyden alta, ja yksilön ideologisten ja muiden inhimillisten uskomusten alta, ja yleensäkin sen kerronnallisuuden alta, jolla me kaikki vakiinnutamme ja vakautamme omaa minäämme.

Olen itse kääntänyt katkelman näin:

Pukkila reefed his small-talk sails. "Belike, belike!" beadled he and babbled in his beard. You certes don't gun grouse 'cept from a goodly gap, and was he going to stand there on the veranda blasting all over the empty walls the charge that'd singe the hairs on Alastalo's chin, but not till they were in the parlor, where a dozen greedy pairs of ears all bout could savor the sweetness? As they'd trudged up the hill from the beach he'd said to Evald, his son: "let 'em build that barque-barque, far's I'm concerned barque-barque! but me I'll salt-salt, salt-salt. Alastalo's got them prodigious ear flaps, right royal ear flaps, lavish landing nets for ears, let's loose us a little word-skeeter into 'em, heigh? They got room! [--] I ain't little and I ain't big, me, I'm Pukkila, and it's Pukkila's squiggly tongue I got in my mouth! Don't laugh, Evald, I ain't laughing when the barbason bolts out of my beard, but see here, while the others laugh, Evald, that's how I goggle 'em!" was how he'd advised his son whenas they was already wiping their feet on the big brushy evergreen branch out in front of the porch. So "belike-belike!" puttered Pukkila, just jawing his own jabs at Alastalo. "Persnickety-rickety wind-went backety, Kivivesi-vesklivity!" burbled he but to breach the bunkum battlements and to train his tongue twisty, and so to block more bitter bubbles from bombarding his ear, his eye peering already over Alastalo's shoulder through the hall into the parlor. (Robinson 2017a, 248; kursivointi lisätty)

Tässä yritän urhoollisesti seurata tuossa purjehdussanastoa (sieppasi reiviä, "reefed"), alkusointuja ("Belike, belike!' beadled he and babbled in his beard") ja vanhahtavaa kielenkäyttöä ('You certes don't gun grouse 'cept from a goodly gap"). Olen myös yrittänyt seurata Pukkilan änkytyksenomaisia toistoja:"rakentakoot, parkin-parkin, minun puolestani parkin-parkin, mutta kyllä minä suolaan-suolaan, suolaan-suolaan!" kääntyy englanniksi "let 'em build that barque-barque, far's I'm concerned barque-barque! but me I'll salt-salt, salt-salt!” Kohta on kuitenkin helppo verrattuna tähän: "Kanitti-kanitti tuulikin-tuulikin vastaan-vastaan Kivivedellä-Kivivedellä". Ilmeisin, mutta myös pienin, kompastuskivi tuossa on kanittaa-verbi: se ei selvästikään tarkoita kirjaimellisesti panttaamista tai jumittamista (tuuli panttasi vastaan? tuuli jumitti vastaan?), eli ehkä Kilpi käytti sitä omin päin, tai sieppasi reiviä jostain edesmenneestä varsinaissuomalaisesta murteesta.

Tätä syvempi sudenkuoppa on se, ettei "Kivivesi" sano suomea taitamattomalle tai Suomea tuntemattomalle lukijalle mitään. Sellainen lukija voi tietysti 


\section{Miten välittää ulkomaalaiselle lukijalle, kuinka paljon}

\section{Kivi merkitsee suomalaisille, ja etenkin merkitsi itse}

\section{Kilvelle?}

katsoa Kiviveden kartalta - jos ylipäänsä hoksaa, että se on paikannimi, Turun saaristossa oleva salmi. Mutta miten välittää ulkomaalaiselle lukijalle, että Kivivesi on paitsi "rock water" myös Aleksis Kiven vettä? Miten välittää ulkomaalaiselle lukijalle, kuinka paljon Kivi merkitsee suomalaisille, ja etenkin merkitsi itse Kilvelle? Ehkei suomalainenkaan lukija tietoisesti huomaa tai ajattele näitä assosiaatioita, mutta jossain alitajunnassa ne vaikuttavat, teroittavat Kilven tekstin kaunokirjallista efektiä. Entä käännöksen lukija? Mitä hän huomaa tai ajattelee? Ja jos on mahdotonta välittää hänelle koko suomalaista kulttuuritaustaa - ja valitettavasti se on tässä kerta kaikkiaan mahdotonta - mitä hänelle voidaan tarjota sen sijaan? Pelkkiä sanojako? Vai jonkinlaista alitajuista tunnetasoista turbulenssia?

Tällaiset huomiot kieltämättä teroittavat Barrettin tunnetta siitä, että Alastalon salissa on mahdoton kääntää. Omassa englanninnoksessani ikään kuin assosioin Pukkilaa Touretten oireyhtymään, joka oudolla tavalla avartaa suomalaisen nälvijän laajemmalle maailmalle. Tulee erityisesti mieleen Oliver Sacksin $(1985,97)$ The Man Who Mistook His Wife for a Hat -kirjan luku nimeltä "Witty Ticcy Ray", vitsikäs ticcikäs Ray:

Kun ensimmäisen kerran näin Rayn hän oli 24-vuotias. Silloin moninaiset äärimmäisen väkivaltaiset tic-liikkeet, jotka puhkesivat rypäleinä aina muutaman sekunnin välein, olivat tehneet hänet lähes työkyvyttömäksi. Hän oli kärsinyt näistä nelivuotiaasta asti, ja niiden herättämä huomio oli vakavasti stigmatisoinut hänet, vaikka hänen älykkyytensä, verbaalinen nokkeluutensa ja vahva luonteensa ja todellisuudentajunsa olivat mahdollistaneet sen, että hän onnistuneesti kävi koulun ja yliopiston, ja että häntä arvosti ja rakasti muutama ystävä ja vaimo. Mutta yliopiston jälkeen hän oli saanut potkut tusinasta työpaikasta, aina ticciensä, ei koskaan epäpätevyyden, vuoksi. Hän joutui jatkuvasti jonkinsorttisiin kriisitilanteisiin, yleensä koska oli niin kärsimätön, riidanhaluinen ja karkean, loistavan ja ylimielisen julkea. Hänen avioliittoaan uhkasivat tahattomat vitut! paskat! -huudot, jotka purkautuivat häneltä seksuaalisen kiihtymyksen hetkinä. Kuten monet touretterit hän oli erikoisen musikaalinen, ja tuskin olisi pysy- 
nyt emotionaalisesti tai taloudellisesti hengissä, ellei hän viikonloppuina olisi ollut jazz-rumpalina todellinen taituri, kuuluisa äkillisistä ja villeistä improvisoinneistaan, jotka nousivat ticistä tai pakonomaisesta rummuniskusta ja sulautuivat välittömästi villiin ja vaikuttavaan improvisaatioon, niin että "yllättävä tunkeilija" kääntyi loistavasti eduksi. Tourettesta oli etua eri peleissäkin, erityisesti pingpongissa, jossa hän loisti, osittain koska hänen refleksinsä ja reaktionsa olivat niin poikkeuksellisen nopeita, mutta etenkin taas hänen improvisiontiensa vuoksi, joita hän itse kuvaili "hyvin äkillisiksi, hermostuneiksi, kevytmielisiksi laukauksiksi". Ne olivat niin odottamattomia ja yllättäviä, että niihin oli käytännössä mahdotonta vastata. (suom. DR) ${ }^{3}$

Tässä neurologisessa yhteydessä Pukkilakin on jotain muuta kuin outo nälvijä: hän on tökkivän luova! Sitä kautta "Kanitti"-lauseesta tulee englanniksi vieläkin töksähtelevämpi.

\section{Luettava Pitäjän pienemmät}

Kuten Pekka Tarkka kertoo, Kilpi käännätti Alastalon "Albatrossin tarinaa" ja Pitäjän pienempien eräitä novelleja Elmer Diktoniuksella ruotsiksi - tai siis yritti. Siihen aikaan, kun Alastalo julkaistiin, Kilpi itse otti yhteyttä Diktoniukseen, joka oli hänen mielestään "veres ja rohkea kielenkäyttäjä", siinä toivossa, että ruotsinnos "saattaisi varmentaa alkukielisen painoksen levikkiä" (Tarkka, toim. 1990, 65; tästä eteenpäin KHK; kirje Alvar Renqvistille 21.5.1933). ${ }^{4}$ Valitettavasti hankkeesta ei tullut mitään: Diktoniukselle työ oli poikkeuksellisen vaikea, ja Kilpi itse oli asiakkaana vielä vaikeampi. Käännöstyö eteni hitaasti, liian hitaasti Kilvelle, joka halusi ruotsinkielisen valikoiman julkaistavaksi jo syksyllä 1933 - jolloin Diktonius vielä kamppaili Kilven erikoisen suomen kanssa. Diktonius lähetti kesän lopulla, 24. elokuuta, kymmenisen liuskaa "Albatrossin tarinasta", valittaen, että "[k]yllä tästä käännöksestä työtä riittää, ja hidasta se on ja luultavasti käsikirjoituksenne paisuu enemmän kuin ne 250 sivua joista puhe oli, mutta jos niin käy ja välttämättä tahdotte kaiken mukaan, on minun vaadittava eri korvaus" (KHK, 223). Kilpi ilmeisesti piti käännösnäytettä alaarvoisena - jäämistöstä puuttuu pari Kilven kirjettä -, koska Diktonius kirjoitti 14. syyskuuta, että "kaikesta päättäen Te myös enskertalaisena odotatte ja vaaditte liian paljon kääntäjältä, sillä luulen parhaimmankin käännöksen antavan vain puolet alkutekstistä” (KHK, 224). Kilpi myönsi kaksi päivää myöhemmin, että "monessa seikassa vaadin mahdottomia" (mp.). Vielä 11 vuotta Kilven kuoleman jälkeen Diktonius tuskaili Kilven vaikeutta (ks. viite 4).

On päivänselvää, että Kilpi odotti liikaa kääntäjältä; on kuitenkin vaikeampi yhtyä siihen Diktoniuksen mielipiteeseen, että paraskin käännös antaa vain puolet alkutekstistä. Ongelma ei ole se, että käännös olisi aina puolet alkutekstiä 
huonompi, vaan se, että loistavan alkutekstin loistavan käännöksen tekeminen vaatii aikaa - ja sitähän kärsimätön Kilpi ei kyennyt Diktoniukselle suomaan.

Pitäjän pienemmissä Kilven kieli on kuitenkin suhteellisen luettavaa:

Ylistalon avaran tuvan kuluneita penkkejä mitattiin uskollisesti, mitattiin Pyhäinmiesten päiviltä Valpuriin syksyn loppu ja talven selkä syksyn lopun ja talven selän jälkeen, mitattiin joulun edun harmailta helmikuun selkeneviin ja huhtikuun jo kilotteleviinkin päiviin aamupuhteen verkkaisista päivän hitaitse ehtoon vilkkaammille räiskymille saakka takkapaaden pinoissa ja valkeoissa. Neljä miestä mahtui mukavasti mittavilleen pitkäkseen sivuseinäpenkille, kolme takalavitsoille pöydän taakse ja perä-akkunan eteen, Iso-Vileenillä oli hyvä tila loikoilla pöydän etupenkillä ja isäntä itse hautoi pitkää selkäänsä vakussa keskellä laattiaa, koivet, jotka olivat mitatut selän mittariitinkien mukaisesti, ratsain roikkumassa vakun kummankin laidan ylitse loitoilla laattioilla. Siinä Mikkelin ja Pyhäinmiesten välillä, joskus myöhemminkin, kuinka kotomatka oli joutunut, välisti vasta joulunkin korvissa, kun laivat taaskin, raa'at hilattuina mastoja pitkin ja purjeet ja köydet korjattuina puolikansien suojiin, keikkuivat ja nykivät ankkurikettinkeissään kotolahdella, olivat meripojatkin hakeneet vanhat talvikontunsa taaskin, ja Ylistalon tupa, suven mittaan vähän uninen ja autio tupa, alkoi täyttyä miesväellä ja kansalla. (Kilpi 1978, 9)

Kyllähän tuon kääntäisi nopeasti, jos ei piittaisi ollenkaan sen kaunokirjallisesta paatoksesta: "The worn benches in the Ylistalo greatroom were measured faithfully, measured from Halloween till May Day, from the end of autumn through to the end of winter [--]”. Jos tärkeintä on välittää sanojen merkitykset, tällaisenkin melko painokkaan tekstin kääntäminen käy näppärästi. Tähän toteamukseen Barrettkin varmasti yhtyisi - hän ei vain pidä moista ala-arvoista käännösstrategiaa kunnollisena kääntämisenä. Tuossa ensimmäisessä lauseessahan Kilven kertoja kuvaa talven ajanjakson kokonaiset kolme kertaa: mitä tämä "toisto" merkitsee? Jos vastaus on "ei mitään", jos tyydymme välittämään pelkät sanojen merkitykset, "The worn benches in the Ylistalo greatroom were measured faithfully all winter" riittäisi mainiosti. Mutta Kilpi ei kirjoittanut näin yksioikoisesti; hän maalaili talvien kulkua seikkaperäisesti, jopa intohimoisesti, hieman oudolla intensiteetillä. "Toisto" ei ole toistoa, vaan uusien kuvaannollisten kerrostumien maalaamista päälle ja alle ja sekaan. Ja miksi kuukausikaupalla juuri mitattiin penkkejä? Se tarkoittaa tietysti, että penkeillä maattiin, penkkien "mittareina" miesten pituudet: miksi? "Aamupuhteen verkkaisista päivän hitaitse ehtoon vilkkaammille räiskymille saakka" on vähän oudosti sanottu, muttei mitenkään vaikeasti ymmärrettävissä: senkin voisi kääntää "all day", mutta Kilpi ei kirjoittanut "koko päivän". Alkaa selvitä, että sanojen tuntu, paino, rytmi, sointu ovat tärkeämpiä kuin niiden merkitykset - tai paremmin, niiden merkitykset ammentavat niiden tunnusta paitsi esteet- 
tisen myös eettisen painonsa. Jos kääntäessä pyrimme käyttämään tätä kaunokirjallista havaintoa merkkipaaluna, se vie aikaa:

Bemeted were the bavin'd benches in the Ylistalo greatroom, bemeted were they bedingly from the All Hallows high days till Saint Valborg's day on the first of May, autumn's haunch and winter's back after autumn's haunch and winter's back, bemeted bateless aye from the Yuletide seres to Februa's fairing and April's bedazzl'd days, day after day from the dark draggy dole ere dawn thro' the dulls o' th' day till the eventide's birringer bashes and bangs in the fardels and flames on the hearthstone. Four fellows could fit fine full-flat-long on the benches 'long the lateral walls, three on the back benches behind the board and before the back window, Big Vilen with a goodly grand span to goldbrick on the board's beforebench, the man of the house his own self baking his long back in the cradle out in the middle of the floor, his pegs, pegg'd to his spinal proportions, a-straddle the cradle's cramp'd gunwales, firm on the far flitches. There 'twixt the Feast of Saint Michael and All Hallows' Eve, some years e'en later, depending on the men's homeward progress, eftsoons nigh Yuletide, when the ships once more, their yards rounded in 'long the masts and the sails and the lines tuck'd 'way 'neath the half-decks, bobb'd and bump'd on their chains in their home harbours, had the old seadogs settl'd back into their winter digs, and the Ylistalo greatroom, which was summers a stead sleepy and stark, began once again to fill with menfolk. (käänt. DR)

Kieltämättä käännökseni paatoksellisuus on vielä Kilven alkutekstiäkin raskaampaa, sen kieli vielä vanhahtavampi. Sekö on huono asia? Ei välttämättä. Käännös tuntuu usein jo sinänsä kevyemmältä kuin alkuteos, pelkästään sen vuoksi, että se on käännös. Se on kuin alkuteoksen varjo, tai peilikuva: ilman omaa ruumiillistumaansa. Jotta käännös alkaisi tuntua todelta, elävältä olennolta, sen jänteitä pitää verbaalisesti sitkeyttää, lihaksia verbanabolisesti pullistuttaa. ${ }^{5}$

\section{Johtimuksellinen Suljetut portit}

Yllä totesin, että Pitäjän pienempien kieli on "suhteellisen luettavaa"; näin se onkin, verrattuna vaikkapa Suljettuihin portteihin $(1938)$. Vilho Suomi $(1944,7)$ kirjoitti tuosta jälkimmäisestä kirjasta: "Kieltämätön vahinko kuitenkin on, että Suljettujen porttien osittain runosäkein rakennettu 'paisuva proosa' - kuten Volter Kilpi itse näitä runorivejään nimitti - kulkee kielellisesti niin loitolla totutusta käytännöstä, että alttiinkin ymmärtämisen tahdon on usein vaikea tavoittaa sanojen takana olevaa ajatusta". 
Esimerkiksi tämä:

\section{BEELZEBUBIN VIRSI}

Kehiänsä kiertävät tähdet ja ihminen, tähdet vain väljissä, ihminen ahtaissa:

Autio tyhjyyskö tähtien teinä, anki orpuusko ihmisen osa?

Hehkujen jähmyynkö taivaan kivetynten kiito, tulesta tuhkiin,

tutkainsa katoonko elon palokerä loimuu liekkinsä syövä?

Rautojen malmeinko kiiluu taivaitten tähtitarha, terhenissä sinen,

jäätävin viluinko kouraa ihmistä elonvalta, väikkämillä onnen? (Kilpi 1938, 37)

Tämä "Beelzebubin virren" ensimmäinen säkeistö on vaikeudessaan aika lailla koko kokoelman edustava näyte; siinä Kilven uudelleenluova ote suomen kieleen huipentuu loistavalla, mutta myös kiusaavalla, tavalla. Keksityt sanat ovat siinä vain vaikeatajuisuuden jäävuoren huippu - vaikkapa "väikkämät" sai paitsi minut, myös joukon fennistejä, joilta kysyin semanttista apua, rapsuttamaan päätään. Kysyin asiasta Twitterissä, mutta kun kukaan siellä ei osannut auttaa, Tiina Kinnunen (2017) välitti kysymykseni Facebookiin. ${ }^{6}$ Seikkaperäinen keskustelu päättyi Anni Tuovisen mietiskelyyn: "Minulle tulee tuosta intuitiivisesti ajatus, että juuri kun on saavuttamaisillaan onnen, vähän niin kuin väijyä, saalistaa, kun onni on näkyvillä [--] vieläpä niin, että onni on vähän niin kuin yhtäkkiä tullut eteen, väijyminen on vähemmän suunniteltua, jotain seikkailun, leikin, väijyn ja myös välkkeen väliltä” - ja Outi Pollarin oivaan yhteenvetoon:

Volter Kilpi on suomen kielen johtimuksellisuuden mahdistus, sanasammon aarteitten suotuma! Kilpi generoi loputtomasti uudissanoja pusertamalla sananytimet johdossiivilänsä läpi ja tuottaa suomalaiselle intuitiivisesti ymmärrettäviä ilmauksia, vaikka liki puolet sanamuodoista on sellaisia, ettei niitä ole ikinä missään muualla nähnyt eikä sanaluokkakarusellissa meinaa pysyä kyydissä! [--] Vaikka tuo "väikkämä" onkin tulkinnanvaraisempi kuin muiden säkeiden loppuosat, niin niihin vertautuessa se tuntuu intuitiivisesti mielestäni enemmän siltä, että onnen mahdollisuuksia väikähtelee elämässä paljonkin ("väikkämillä" on monikossa!), mutta silti elonvalta saatta "jäätävin viluin kourata". 
"Johtimuksellisuuden mahdistus"! Sepä on Kilpi juuri. Tämän Facebook-keskustelun perusteella viimeistelin säkeistön englanniksi:

\section{BEELZEBUB'S HYMN}

Stars and we humans all orbit our ambits, stars around loosely, humans more tightly: black barren emptiness stars' stinging streates, bleak barren orphood our creaturely kismet?

Flying fires festinate fizzle and fume, embers to ash?

Bio's blazeball glows till its goad goes tabid, its flames consumed?

Starry sky glimmers like ore of our irons in the wispy welkin?

Buffets a body biopower with the frostiest chill, hapless its happenstance? (käänt. DR)

Olen tuossa harjoittanut hieman omaakin johtimuksellisuuttani, vaikken välttämättä Kilven veroisella mahdistuksella: alkusoinnut, streets $>$ streates, orphanhood>orphood; elon palokerästä tulee "bio’s blazeball"; jähmystä vanhahtava "tabid"; elonvallalle lainasin Michel Foucault'n keksinnön "biopower"; ja lähestyin "väikkämillä onnen" leikkimällä hap-sanalla, joka vanhassa englannissa tarkoittaa sattumaa ("chance, coincidence" mistä "to happen", sattua) tai onnea merkityksessä "luck, fortune", mutta myös myöhemmin onnea merkityksessä "happiness". "Hapless" ihminen on onneton sikäli, että mikään ei luonnistu; "hapless happenstance" olisi onneton sattuma. Ei välttämättä onnen väikkämät: en menisi vieläkään väittämään, että ymmärrän tuon viimeisen säkeen.

\section{Postuumi Gulliverin matka Fantomimian mantereelle}

Kilven jälkeenjäänyt romaani Gulliverin matka Fantomimian mantereelle on jäänyt Suomessa Saaristosarjan varjoon, vaikka se on ilmeisen kiinnostava ja olen sen nyt kokonaisuudessaan kääntänyt Jonathan Swiftin aikaiseen englantiin myös kirjoittanut loppuun, Kilven omien suunnitelmien mukaisesti. Mikä siinä siis kiinnostaa?

Gulliver on lyhyempi ja helpompi kuin Alastalo, ja siinä on tavallaan seikkailuromaanin juoni. Kurimuksen kierrossa kertoja kyllä eksyy monta lukua peräkkäin filosofoimaan elämästä ja kuolemasta, ja vuoden 1938 Lontoossa hän eksyy väsyttävän pitkään purnaamaan tekijänsä puolesta modernin maailman epäinhimillisyydestä - mutta silti tarina kulkee vikkelämmin kuin Saaristosarjan monisäikeiset kerronnat. Totta on myös, että "kääntäjän esipuheessaan" 
Kilpi eksplisiittisesti viittaa oman oudon suomenkielisen tyylinsä "yli" tai ohi Gulliverin (ja implisiittisesti Swiftin) 1700-alun englanninkieliseen proosaan: englannintajan kohdekieli on tavallaan jo olemassa. Uutta englanninkielistä vastinetta sille oudolle tyylille ei siis tarvinnut loihtia tyhjästä esiin, "johtimuksellisesti" - saatoin sen sijaan matkia Swiftiä.

Tärkein syy valinnalleni oli kuitenkin Kilven esipuhe, jossa hän fiktiivisesti esittää romaaninsa käännöksenä. Hän väittäälöytäneensä vanhan paperipinkan-

Olen toimeltani kirjastonhoitaja, ja virkatyö tuo käsiini paitsi painettua sanaa tukuttain muutakin paperijätettä. Sattuipa täten kerta vuorolleen muuan tukeva käärepinkkakin, vahvalla vanhanaikaisella purjenarulla nyörätty ja pahasti pölyttynyt. Huomasin kohta, että käärö sisälsi kymmenkunta harmaisiin, hapuriin paperikansiin nidottua vihkosta, hyvin kuluneita ja mustuneita, mutta ilmeisesti sentään verrattain eheinä säilyneitä. [--] Huomiotani kiinnitti kohta, paitsi tavallinen vanhan paperin tunkka, se ominainen haju, jonka paperi imee itseensä, kun sitä kauan on säilytetty kosteassa ja vähän ummehtuneessa laivan kajuutassa. (Kilpi 1993, 23; tästä eteenpäin GMFM)

- ja suomentaneensa sen:

Koska tämänlaatuinen harvinaisuus - olkoon sen johto Gulliverin omakätisyyteen jonkinverran hypoteettinenkin - kuitenkin kuuluu lukevalle yleisölle, niin olen tehnyt kustantajani kanssa sopimuksen käsikirjoituksen julkaisemisesta siinä täydellisyydessä, missä se on säilynyt. Lukijapiirien vuoksi ei käsikirjoitusta kuitenkaan julkaista alkuperäisessä muodossaan, vaan suomenkielisenä käännöksenä. (GMFM, 27-28)

Kaunokirjallisuuden historiassa tunnetaan monta sellaista tapausta, jossa kirjailija olisi esittänyt oman alkuperäisen romaaninsa käännöksenä - tällaisia teoksia ovat muun muassa Rabelais'n Gargantua ja Pantagruel ja Cervantesin Don Quijote - ikään kuin vakuuttaakseen meille, ettei hän ole itse vaikuttanut millään lailla teoksen syntyyn. Swiftin Gulliverin matkat oli sikäli samanlainen teos, että Swift esitti sen muistelmateoksena, jonka Lemuel Gulliver oli jättänyt kustantajalleen - se ei siis muka ollut Swiftin itsensä kirjoittama. Se erosi "löydetyn käännöksen" fiktiosta vain siinä, ettei mukakääntäjä ollut muka tullut väliin.

Saatoin kääntäjänä paitsi tukeutua Swiftin englantiin myös antaa tukea Kilven omalle fiktiiviselle väitteelle siitä, ettei hän itse olisi sitä kirjoittanut, vaan löysi ja suomensi sen. Saatoin kääntäjänä mennä samaan väitteeseen mukaan: itse muka löysin saman englanninkielisen paperipinkan ja toimitin sen englanniksi. Sillä tavalla saatoin siis jatkaa Kilven epistemologista leikkiä. 


\section{Alkaa selvitä, että sanojen tuntu, paino, rytmi, sointu ovat tärkeämpiä kuin niiden merkitykset - tai paremmin, niiden merkitykset ammentavat niiden tunnusta paitsi}

esteettisen myös eettisen painonsa.

Missä mielessä leikki on epistemologinen? Tällä vanhalla fiktiivisellä jekulla on pitkän kaunokirjallisen historian kautta toisaalta luotu illuusio kerrottujen tapahtumien "todenperäisyydestä": koska teoksen kirjoitti omalla kädellään sen kertoja ja päähenkilö, muistelmateoksena se (muka) kertoo tositarinan. Toisaalta sillä on samalla myös leikitelty realismin illuusiolla, jotta lukijaa Schlegelin sanoin johdateltaisiin "kerta toisensa jälkeen ensin uskomaan ja sitten olemaan uskomatta": tarina on yhtaikaa totta ja valhetta, vuorotellen uskottavaa fiktiota ja täysin epäuskottavaa oikeaa elämää.

Jos siis Kilpi väitti kääntäneensä löytämänsä tarinan, itse kääntäjänä saatoin väittää löytäneeni saman paperipinkan ja toimittaneeni sen. Sehän oli muka alun perin englanninkielinen: ei siis periaatteessa tarvitsisi kääntää! Todellisuudessa olisin kiltisti kääntänyt Kilven kirjoittaman osan ja kirjoittanut romaanin loppuun, Kilven ohjeiden mukaan - mutta Kilven oman fiktiivisen leikin mukaisesti olisin koko löydetyn teoksen toimittaja.

Tämä oivallus se minua työhön innostikin. Sen inspiroimana loin teoskokonaisuuden, jossa jokainen sana oli minun itse englanniksi kääntämä/kirjoittama, mutta jonka esitin sattumalta löytämänäni ja sitten toimittamanani 1700-luvun englanninkielisenä käsikirjoituksena. (En pyrkinyt kuitenkaan petkuttamaan lukijaa: kansien sisällä myös loin fiktiiviset "kriitikon" ja "kustantajan", jotka kumoavat väitteen teoksen toimittamisesta, ja sekä etu- että takakannessa identifioin teoksen Kilven kirjoittamaksi ja minun kääntämäkseni ja loppuun kirjoittamakseni.) Teoskokonaisuuteen kuuluu, paitsi Kilven keskenjääneen romaanin englanninnos, myös:

* johdanto, jossa hieman vainoharhainen "Douglas Robinson" kertoo "löytäneensä" uudelleen sen 1700-luvun käsikirjoituksen, jonka Kilpi kertoo löytäneensä Turun yliopiston kirjastossa - mikä siis tarkoittaisi, että koko romaani olisi ehkä Swiftin itse kirjoittama ja Kilven suomentama (mutta ehkä myös sitä, että "Douglas Robinson" olisi seonnut); 
* sarja itse kirjoittamiani "muistiinpanoja" Ezra Poundin ja muiden vuonna 1915 laatimaa "Vorticist"-manifestia varten, ideana että manifestin anonyymit kirjoittajat löysivät sen "alkuperäisen" englanninkielisen käsikirjoituksen jo ennen Kilpeä, ja kanavoivat ensimmäisen osan kurimuskuvastoa manifestiinsa;

* englannintamani Kilven "kääntäjän esipuhe", jossa hän kertoo löytäneensä Turun yliopiston kirjastossa vanhan (ehkä itse Lemuel Gulliverin kirjoittaman) englanninkielisen käsikirjoituksen ja kääntäneensä sen suomeksi;

* peitenimellä kirjoittamani arvio, jonka mukakirjoittaja, suomalainen Kilpi-tutkija, tyrmää "toimittajuuden" hävyttömänä huijauksena;

* kirjoittamani romaanin jatko (kotiinpaluuseen saakka).

Kääntäjän toimittajaksi tekeytyminen on siis tarkoitettu samanlaiseksi fiktiiviseksi leikiksi kuin Kilven väite, että hän olisi ollut englanninkielisen teoksen löytäjä ja suomentaja. Tavallaan se on jopa sama leikki: "kääntäjä-Kilpi" ja "toimittaja-kääntäjä" molemmat leikittelevät, että käsissä oleva kirja olisi alun perin ollut 1700-luvulla englanniksi kirjoitettu käsikirjoitus. Schlegelin sanoin tämä leikki on "ei-mielivaltainen, jopa täysin loppuunajateltu valepuku", jota "on yhtä mahdoton taiteilla tai paljastaa". Kilpi oli kirjailija, joka väitti olevansa kääntäjä; kääntäjä taas väittää olevansa toimittaja. Koska kääntäjänä lisäilen tekstiin omianikin - fiktiivisen johdannon, tarinan jatkon, kritiikin - olen itse asiassa osittain kirjailijakin. Mutta samalla olen ilmeisen selvästi merkinnyt Kilven kirjoittamat 25 lukua Kilven kirjoittamiksi, ja ilmoittanut kääntäneeni ja kirjoittaneeni loppuun Kilven keskenjättäneen alkuperäisen romaanin. Se on postmoderni kokonaisuus, josta modernisti-Kilpi olisi ehkä nauttinutkin.

Näytteeksi:

Parina viime vuotena, kertoo Cartwright, on hän iltikseen, kun ei enää valaitakaan missään tapaa, niitäkin kait kun läkähdyttää tämä lähtemätön lämpimän sulja meressä, luoviskellut kauas sivu Huippuvuorien pohjoista kohti tapaamatta sensiruista jäänkahvaletta meressä uiskentelemassa, että edes rommipullonsa jäähdykettä olisi onkinut pytsyyn. (GMFM, 32)

Tuossa on kolme kilpimäistä johtimeksellisuutta: sulja, sensiruinen, jäänkahvale. Lisäksi hän käyttää vanhaa murresanaa pytsy (purjekangassanko) ja vanhahtavia adverbeja iltikseen ja sivu (merkityksessä ohitse, sivuitse). Sen voisi englannintaa kirjaimellisesti näin:

In [the] last couple years, says Cartwright, has he unobstructed, since [he] no longer whales anywhere finds, they too presumably feeling stifled by 
this undeparting unfrozen area of warmth in the sea, navigated far [along] side the Spitzbergen toward [the] north without finding an ice-handle of sufficient chipness swimming in the sea, that even [enough for] his rum bottle's coolant [he] could fish into a bucket.

Tai sitten sen voisi kääntää vähän vapaammin näin:

In the last few years, Cartwright says, finding no whales anywhere - they too presumably finding the unrelenting warmth in the sea too hot for comfort - he has sailed past the Spitzbergen far to the north without finding enough of an iceberg to cool off a bottle of rum.

Mutta kun Kilpi väittää, että tarinan kirjoitti itse Gulliver, tai sitten joku muu engelsmanni jo 1700-luvun alussa, kaksi vuosisataa ennen häntä, on silkkaa laiskuutta kääntää romaani moderniin englantiin. Itse sen sijaan mukailen Jonathan Swiftin englantia näin:

O'er the past few Years, Cartwright says, finding not a Whale any where he sails, they too presumably feeling oppress'd by this perpetuall tropickall Sultre in the Sea, he has set him a Course thro' open unblock'd Waters up past the Spitzbergen Northward without glimpsing a-swim in the Sea e'en a blue Sliver of an Iceberg, sufficient to cool off his Flagon o' Rum. (Robinson, käänt. ja toim. 2020b [tulossa])

Kuten nykysaksassa, 1700-luvun alun englannissa kirjoitettiin kaikki substantiivit isoilla kirjaimilla; siihen aikaan kaikki nimet kursivoitiin; sanojen lyhennetyt muodot (oppress'd, thro', unblock'd, e'en, o'), kuten myös vanhahtavat oikeinkirjoitukset (perpetuall tropickall pro perpetual tropical), olivat yleisiä. Sultre on kilpimäinen johtimeksellisuus sanasta "sultry" (lämmin). Pytsy on jäänyt kokonaan pois kuviosta; lauseke "tapaamatta sensiruista jäänkahvaletta meressä uiskentelemassa" on nyt "without glimpsing a-swim in the Sea e'en a blue Sliver of an Iceberg".

Niin kiehtova kuin tämä Gulliver-projekti minulle kieltämättä on, se on loppujen lopuksi vain esimakua Alastalolle. Minusta on jännällä (ei välttämättä sokraattisella) tavalla ironista, että kauan, yli vuosikymmenen, kerroin kaikille että jonain päivänä, ehkä vasta eläkepäivilläni, englanninnan Seitsemän veljestä, joka on, lisäsin, suomesta englannintamisen Everest-vuori. Mutta heti kun olin sen jättiläisvuoren huipulle kiivennyt ja julkaissut oman The Brothers Sevenini, löysin Kilven Alastalon, joka on vielä vaikeampi, vielä pitempi, mahdollisesti jopa vielä nerokkaampi kuin Kiven Veljekset - ja nyt kerron kaikille, että jonain päivänä, ehkä vasta eläkepäivilläni, englanninnan Alastalon salissa, joka on suomesta englannintamisen Everest-vuori. 


\section{Viitteet}

1 Reluctantly (I really have tried) I have been driven to conclude that Alastalon salissa is untranslatable, except perhaps by a fanatical Volter Kilpi enthusiast who is prepared to devote a life time to it. To mention only one of the difficulties, there is no English equivalent to the style of the Finnish 'proverbs' (real or imaginary) with which the main character Alastalo's thoughts are so thickly larded. Add to this the richness and, yes, eccentricity, of Kilpi's vocabulary, and the unfamiliarity of much of the subject-matter, centred as it is on the interests of a sea going community that hardly exists any longer, even on the islands, and you have a text that is full of pitfalls for the translator. As for the humour, I'm sorry to say that it depends so much on the idiom and presentation that it doesn't come over at all. IfI did any more, I'm afraid it would just have to be a laborious paraphrase, and I don't think I'm capable of making it effective, or even readable, in English.

2 Die Sokratische Ironie ist die einzige durchaus unwillkürliche, und doch durchaus besonnene Verstellung. Es ist gleich unmöglich sie zu erkünsteln, und sie zu verraten. [--] In Ihr soll alles Scherz und alles Ernst sein, alles treuherzig offen, und alles tief verstellt. [--] Sie enthält und erregt ein Gefühl von dem unauflöslichen Widerstreit des Unbedingten und des Bedingten, der Unmöglichkeit und Notwendigkeit einer vollständigen Mitteilung. Sie ist die freieste aller Lizensen, denn durch die setzt man sich über sich selbst hinweg; und doch auch die gesetzlichste, den sie ist unbedingt notwendig. Es ist ein sehr gutes Zeichen, wenn die harmonisch Patten gar nicht wissen, wie sie diese stete Selbstparodie zu nehmen haben, immer wieder von neuem glauben und mißglauben, bis sie schwindlicht werden, den Scherz grade für Ernst, und den Ernst für Scherz halten.

3 When I first saw Ray he was 24 years old, and almost incapacitated by multiple tics of extreme violence coming in volleys every few seconds. He had been subject to these since the age of four and severely stigmatised by the attention they aroused, though his high intelligence, his wit, his strength of character and sense of reality enabled him to pass successfully through school and college, and to be valued and loved by a few friends and his wife. Since leaving college, however, he had been fired from a dozen jobs - always because of tics, never for incompetence-was continually in crises of one sort and another, usually caused by his impatience, his pugnacity, and his coarse, brilliant "chutzpah", and had found his marriage threatened by involuntary cries of "Fuck!" “Shit!", and so on, which would burst from him at times of sexual excitement. He was (like many Touretters) remarkably musical, and could scarcely have survived-emotionally or economicallyhad he not been a weekend jazz drummer of real virtuosity, famous for his sudden and wild extemporisations, which would arise from a tic or a compulsive hitting of a drum and would instantly be made the nucleus of a wild and wonderful improvisation, so that the "sudden intruder" would be turned to brilliant advantage. His Tourette's was also of advantage in various games, especially ping-pong, at which he excelled, partly in consequence of his abnormal quickness of 
reflex and reaction, but especially, again, because of "improvisations", "very sudden, nervous, frivolous shots" (in his own words), which were so unexpected and startling as to be virtually unanswerable.

4 Pekka Tarkan tarkempi selostus tästä kirjeenvaihdosta: "Bonnierin arkistossa ei ole Diktoniuksen Kilpi-käännöksiä eikä Olaf Homénin esipuhetta. Sen sijaan siellä on kirjeenvaihtoa kesältä 1950 Bonniers Litterära Magasinin päätoimittajan Åke Runnquistin kanssa. Runnquist halusi lehteensä Kilpeä, ja Diktonius vastasi 7.8.1950: 'Mitä sitten Kilpeen tulee, hän on tyylillisesti pahin pirulainen mitä maailmankirjallisuudessa tunnen: hän loi kokonaan oman kielensä jossa tuntee olevansa kuin noviisi apotin edessä, mutta minä olen tutkistellut häntä aika pitkään-muutaman viikon päästä Te saatte ehkä muutaman liuskan sitä lajia; enempää tuskin voin luvata" (KHK, 234).

5 Puolustan Saarikosken romaanikäännöstä Sieppari ruispellossa samasta syystä. Epäilemättä Saarikosken Holden on kertojana härskimpi kuin Salingerin: sen vuoksihan suomennos elää. Ks. Robinson (2009; 2007: 84-87).

6 Keskustelu on arkistoituna: https:// www.facebook.com/tiina.kinnunen/ posts/10154556760688645?comment_ id=10154558626563645\&notif_t=like\&notif_ id $=1486450972661342$.

\section{Kirjallisuus}

Barrett, David 1996. A Letter from the Translator. Books from Finland 30(1). http://www.booksfromfinland.fi/1996/03/plain-sailing/.

Kilpi, Volter 1938. Suljetuilla porteilla. Helsinki: Otava.

Kilpi, Volter 1978 (1934). Pitäjän pienempiä: Saaristoväkeä arkisillaan. Helsinki: Otava.

Kilpi, Volter 1993 (1944). Gulliverin matka Fantomimian mantereelle (=CMFM). Helsinki: Kensington.

Kilpi, Volter 2015 (1933). Alastalon salissa. Helsinki: Otava.

Kinnunen, Tiina Helena 2017. Kääntäjä Doug Robinson kyselee Twitterissä. Facebook 6.2.2017. https://www.facebook.com/tiina.kinnunen/ posts/101545567606888645?comment_id=10154558626563645.

Robinson, Douglas, käänt. 1993. Aleksis Kivi, Heath Cobblers (Nummisuutarit) and Kullervo. St. Cloud, MN: North Star Press of St. Cloud.

Robinson, Douglas 2007. Pentinpeijaiset: Romaani. Suom. Kimmo Lilja. Helsinki: Avain.

Robinson, Douglas 2009. Adding a Voice or Two: Translating Pentti Saarikoski for a Novel. Teoksessa Northern Lights: Translation in the Nordic Countries. Ed. B. J. Epstein. Bern: Peter Lang, 213-38.

Robinson, Douglas 2017a. Aleksis Kivi and/as World Literature. Leiden \& Boston: Brill.

Robinson, Douglas, käänt. 2017b. Aleksis Kivi, The Brothers Seven: A Tale. Bukarest: Zeta Books.

Robinson, Douglas, käänt. 2020a. Mia Kankimäki, The Women I Think about at Night. New York: Simon \& Schuster.

Robinson, Douglas, käänt. ja toim. 2020 b (tulossa). Volter Kilpi, Gulliver's Voyage to Phantomimia. Bukarest: Zeta Books.

Rojola, Lea 1995. Varmuuden vuoksi: Modernin representaatio Volter Kilven Saaristosarjassa. Suomalaisen Kirjallisuuden Seuran Toimituksia 627. Helsinki: SKS. 
Sacks, Oliver 1985. The Man Who Mistook His Wife for a Hat, and Other Clinical Tales. New York: Harper \& Row.

Schlegel, Friedrich von 1956 (1798). Fragmente. Teoksessa Schriften und Fragmente: Ein Cesamtbild seines Ceistes. Hrsg. Ernst Behler. Stuttgart: Alfred Kröner Verlag, 81-113.

Suomi, Vilho 1944. Volter Kilven jälkeenjäänyt teos. Teoksessa Kilpi 1993, 5-20.

Tarkka, Pekka, toim. 1990. Kirjailija ja hänen kustantajansa: Volter Kilven ja Alvar Renqvistin kirjeenvaihto 1931-1938 (=KHK). Helsinki: Otava. 